\title{
Pentacyclic triterpenes and steroids from the stem bark of uchi (Sacoglottis uchi, Humiriaceae)
}

Viviane Gomes da Costa ABREU ${ }^{1 *}$, Geone Maia CORRÊA ${ }^{1,2}$, Izandina Aparecida dos Santos LAGOS 3 , Roqueline Rodrigues SILVA ${ }^{1}$, Antônio F. de C. ALCÂNTARA ${ }^{1}$

\section{ABSTRACT}

The ethanol extract from stem bark of Sacoglottis uchi Huber (popularly known as "uchi" in the Amazon Region) was submitted to chromatographic fractionation. The dichloromethane fractions provided the pentacyclic triterpene 3-oxo-friedelin (1). The dichloromethane:methanol fractions provided the pentacyclic triterpenes pseudotaraxasterol (2), lupeol (3), $\alpha$-amyrin (4), betulin (5), and methyl $2 \beta, 3 \beta$-dihydroxy-urs-12-en-28-oate (6) and a mixture of the steroids sitosterol (7) and stigmasterol (8). Their chemical structures were determined by NMR spectroscopy and comparison with spectroscopic data from the literature. All compounds are described for the first time in this species.

KEYWORDS: Humiriaceae, medicinal plants, Amazon Region, triterpenes

\section{Triterpenos pentacíclicos e esteróides da casca do uchi (Sacoglottis uchi, Humiriaceae)}

\section{RESUMO}

O extrato etanólico da casca do caule de Sacoglottis uchi Huber (conhecida popularmente como "uchi" na Amazônia) foi submetido a fracionamento cromatográfico. As fraçóes eluídas com diclorometano forneceram o triterpeno pentacíclico 3-oxofriedelina (1). As fraçôes em diclorometano:metanol forneceram os triterpenos pentacíclicos pseudotaraxasterol (2), lupeol (3), $\alpha$-amirina (4), betulina (5) e $2 \beta, 3 \beta$-di-hidroxi-urs-12-en-28-oato de metila (6), além de uma mistura dos esteróides sitosterol (7) e estigmasterol (8). Suas estruturas químicas foram determinadas por espectroscopia de RMN e comparação com os dados espectroscópicos descritos na literatura. Todas as substâncias isoladas são descritas pela primeira vez nesta espécie.

PALAVRAS-CHAVE: Humiriaceae, planta medicinal, Região Amazônica, triterpenos

${ }_{1}^{1}$ Departamento de Química, ICEx, Universidade Federal de Minas Gerais, UFMG, 31270-901 Belo Horizonte - MG, Brazil - vivianegca@ufmg.br, roquelinersm@qui.ufmg.br, aalcantara@zeus.qui.ufmg.br

2 Instituto de Ciências Exatas e Tecnologia, Universidade Federal do Amazonas, UFAM, 69100-000 Itacoatiara - AM, Brazil - geonemaia@ufam.edu.br

3 Coordenação de Pesquisas em Produtos Naturais, Instituto Nacional de Pesquisas da Amazônia, INPA, 69080-971 Manaus, AM - Brazil - izandina@inpa.gov.br 
The genus Sacoglottis (Humiriaceae) is represented by nine species which are mostly found in the Americas as large trees in tropical regions or small scrubs in neotropical ones (Gentry, 1977). Only the species S. gabonensis is found in the Western of the Africa. The species S. uchi Huber [sin. Endopleura uchi] is found in highland of the Amazon Forest and is popularly known as "uchi", "uxi”, "uxi-amarelo", "pururu", "uxi-liso", "uxi-ordinário" or "uchi-pucu" (Politi et al. 2010). The wood of this species is widely used in civil and naval constructions and the fruits are an important food in rural communities of the Amazon Region (Shanley et al. 2002). Moreover, the macerated bark is popularly used for the treatment of arthritis, diabetes, and inflammations (Magalhães et al. 2007).

The literature reports few chemical studies about $S$. uchi. The fruit pulp contains oleic acid and trans- $\beta$-carotene as majority components, besides other carotenoid compounds (Silva et al. 2009). Recently, we described the isolation of (+)-bergenin from the bark of this species (Abreu et al. 2008). Bergenin exhibits high antioxidant activity and is widely used by oriental folk medicine for the liver disease treatment (Takahashi et al. 2003).

The present work describes the isolation of other constituents from the bark of $S$. uchi (Figure 1). The pentacyclic triterpenes 3-oxo-friedelin (1), pseudotaraxasterol (2), lupeol (3), $\alpha$-amyrin (4), betulin (5), and methyl $2 \beta, 3 \beta$ dihydroxy-urs-12-en-28-oate (6) and the mixture of the steroids sitosterol (7) and stigmasterol (8) were identified by IR and $1 \mathrm{D}$ and $2 \mathrm{D}$ NMR analyses. The compounds $1-8$ were isolated for the first time in this species.

The stem barks of S. uchi were collected in February 2004 in the City of Manaus (State of Amazonas, Brazil). A voucher specimen of the plant was deposited in the herbarium of the Instituto Nacional de Pesquisas da Amazônia (INPA), under the code 82,627.
The stem barks were dried at room temperature and milled, giving $3.0 \mathrm{~kg}$ of powdered material. This material was submitted to extraction with ethanol at room temperature, providing the ethanol extract (EE; $11.83 \mathrm{~g}$ ). The $\mathrm{EE}$ was submitted to column chromatography (CC) using silica gel as stationary phase and eluted with pure or mixtures of hexane, dichloromethane (DCM), and methanol. Chromatographic fractionation of EE was followed by thin layer chromatography (TLC) employing silica gel with fluorescence indicator $\mathrm{F}_{254}$ and monitored under UV light and iodine vapor, to give 74 fractions. The similar fractions were combined in groups based on TLC analysis.

The Group 1 (eluted with DCM) provided a white solid (1; $8.0 \mathrm{mg}$ ). The Group 2 (eluted with mixture of DCM/MeOH 10:1) provided a white solid $(2 ; 11.0 \mathrm{mg})$. The Group 3 (eluted with mixture $\mathrm{DCM} / \mathrm{MeOH} 3: 1)$ provided a white crystalline solid (mixture of 3-6; $15.0 \mathrm{mg}$ ). The Group 4 (eluted with mixture $\mathrm{DCM} / \mathrm{MeOH} 2: 1)$ provided a white crystalline solid (mixture of 7-8; $13.0 \mathrm{mg}$ ).

The melting points (m.p.) were measured on a Mettler model FP62 apparatus. The IR spectra were recorded on the FT-IR Spectrometer Bomem-M102 and Perkin-Elmer Spectrum 2000 FTIR equipments, using $\mathrm{KBr}$ as support. The ${ }^{1} \mathrm{H}$ and ${ }^{13} \mathrm{C}$ NMR spectra were recorded on a Bruker DRX 400 - AVANCE equipment, with probes and inverse gradient of the operative field in 400.129 and $100.613 \mathrm{MHz}$, respectively. Samples $(8.0-15.0 \mathrm{mg})$ were dissolved in $0.75 \mathrm{~mL}$ of $\mathrm{CDCl}_{3}$ and transferred to a tube $5 \mathrm{~mm}$. TMS was used as internal reference for NMR chemical shifts $\left(\delta_{\mathrm{H}}=0.00\right)$, scale in ppm and coupling constants $(/)$ in Hertz. The experiments were performed using pulse sequences and programs provided by the manufacturer. The $1 \mathrm{D}$ NMR $\left({ }^{1} \mathrm{H}\right.$ and ${ }^{13} \mathrm{C}$ NMR $)$ data were acquired under normal conditions, using a direct detection 5 $\mathrm{mm}$ probe ${ }^{1} \mathrm{H} /{ }^{13} \mathrm{C}$ double.

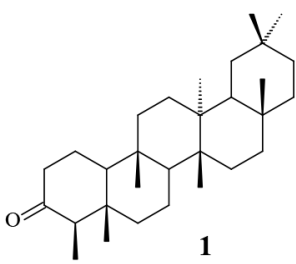<smiles>CCC12CC=C(C)C(C)C1C1CCC3C(CCC4C(C)C(OC(C)=O)CCC43C)C1CC2</smiles><smiles>C=C(C)C1C(C)C2CCC34CCC(O)C(C)(C)C3CCC3C4CCCC3(CC)CCC21</smiles>

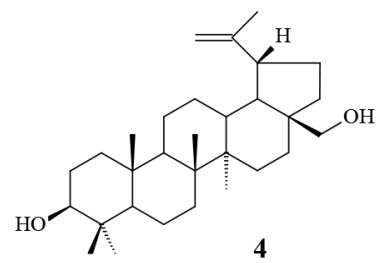

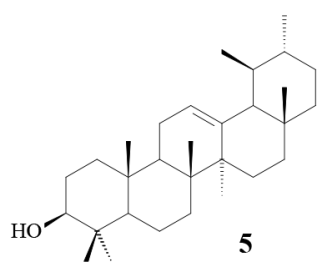

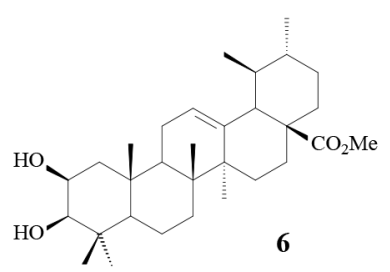<smiles>CCC(CCC(C)C(C)CCC1CCC2C3CC=C4CC(O)CCC4(C)C3CCC12C)C(C)C(C)CCC(C)C1CCC2C3CC=C4CC(O)CCC4(C)C3CCC12C</smiles>

Figure 1 - Chemical structure of the pentacyclic triterpenes (1 to 6) and steroids (7 and 8) isolated from Sacoglottis uchi. 
The IR data of 1 (m.p. $262-264^{\circ} \mathrm{C}$ ) show an intense absorption at $1730 \mathrm{~cm}^{-1}$ which was attributed to $\mathrm{C}=\mathrm{O}$ stretch of ketones. The $1 \mathrm{H}$ NMR spectrum of $\mathbf{1}$ shows several overlapped signals in the characteristic region of aliphatic hydrogen atoms. $1 \mathrm{H}$ NMR ( $\left.400 \mathrm{MHz} ; \mathrm{CDCl}_{3:} \mathrm{ppm}\right): \delta_{\mathrm{H}}$ 2.36-1.22 (overlapping signals), $1.25\left(s, \mathrm{CH}_{3}\right), 1.18\left(s, \mathrm{CH}_{3}\right)$, $1.05\left(s, \mathrm{CH}_{3}\right), 1.01\left(s, \mathrm{CH}_{3}\right), 0.95\left(s, \mathrm{CH}_{3}\right), 0.89\left(s, \mathrm{CH}_{3}\right), 0.84$ $\left(s, \mathrm{CH}_{3}\right)$, and $0.73\left(s, \mathrm{CH}_{3}\right)$. The $13 \mathrm{C} \mathrm{NMR} \mathrm{spectrum} \mathrm{shows}$ a signal at $\delta_{\mathrm{C}} 213.2$ (assigned to a carbonyl carbon of ketone) and other signals which are characteristic of saturated carbon atoms. The ${ }^{13} \mathrm{C}$ NMR data of $\mathbf{1}$ (Table 1) are in agreement with the corresponding data of the triterpene friedelin (Abreu et al. 2011).

Friedelin has been isolated from many vegetal species, such as roots of Vismia laurentii (Nguemeving et al. 2006) and leaves of Maytenus salicifolia (Miranda et al. 2006). Friedelin shows cytotoxicity against the human tumor cell lines (Mossi et al. 2004) and gastric antiulcerogenic and leishmanicidal activities (Surendra and Corey 2009; (Santos-Torres et al. 2004)

The $1 \mathrm{H}$ NMR spectrum of 2 shows a large signal at $\delta_{\mathrm{H}} 5.26$ $(d, J=6.2 \mathrm{~Hz})$ which is characteristic of alkenyl hydrogen. The signal at $\delta_{\mathrm{H}} 3.21(d d, J=10.0$ and $5.6 \mathrm{~Hz})$ was attributed to carbinolic hydrogen. The ${ }^{13} \mathrm{C}$ NMR spectrum shows signals at $\delta_{\mathrm{C}} 140.1$ and 119.7 which are attributed to alkenyl carbon atoms. The ${ }^{13} \mathrm{C}$ NMR data of 2 (Table 1 ) are in agreement with the correspondent data of the triterpene pseudotaraxasterol (Abreu et al. 2011). This compound exhibits antimicrobial activity against Escherichia coli and Bacilus subtilis (Xie et al. 2005) and are described for the first time in the genus Sacoglottis.

The ${ }^{13} \mathrm{C}$ NMR spectrum of Group 3 shows signals attributed to olefinic carbon atoms of triterpenes with lup20(29)-ene-type skeleton $\left(3: \delta_{C} 150.9\right.$ and $109.3 ; 4: \delta_{C} 150.7$ and 109.7) and urs-12-ene-type skeleton $\left(5: \delta_{\mathrm{C}} 124.5\right.$ and 139.9; 6: $\delta_{\mathrm{C}} 126.9$ and 138.3), as shown in Table 1. The signals at $\delta_{\mathrm{C}} 78.9$ and 79.1 are attributed to carbinol carbon atoms. The ${ }^{13} \mathrm{C}$ NMR data of 3 to 6 (Table 1) are in agreement with the corresponding data of the triterpenes lupeol, betulin, $\alpha$-amyrin, and methyl 2 $\beta, 3 \beta$-dihydroxy-urs-12-en-28-oate, respectively (Abreu et al. 2011).

Lupeol exhibits anti-inflammatory and antitumor activities (Geetha and Varalakshmi 1998). The compound $\alpha$-amyrin exhibits anti-inflammatory (Hasmeda et al. 1999), insecticide, and anti-arthritic activities (Kweifio-Okai 1991). Betulin exhibits antitumor and antiviral activities (Mullaer et al. 2009; Bori et al. 2012).

The IR data of the Group 4 show weak absorptions between 1680 and $1650 \mathrm{~cm}^{-1}$ which are attributed to $C=C$ stretchs. The absorptions at 1410 and $1185 \mathrm{~cm}^{-1}$ are attributed to the angular deformation of methyl groups and C-O stretch,
Table 1 - ${ }^{13} \mathrm{C}$ NMR data of the pentacyclic triterpenes isolated from Sacoglottis uchi

\begin{tabular}{lcccccc}
\hline \multirow{2}{*}{ Carbon } & \multicolumn{5}{c}{ Compound } \\
\cline { 2 - 7 } & 1 & 2 & 3 & 4 & 5 & 6 \\
\hline C-1 & 22.3 & 39.0 & 38.7 & 38.8 & 38.7 & 44.9 \\
\hline C-2 & 41.2 & 27.6 & 27.4 & 27.2 & 27.2 & 71.9 \\
\hline C-3 & 213.2 & 79.2 & 79.1 & 79.1 & 79.1 & 79.1 \\
\hline C-4 & 58.2 & 39.1 & 38.9 & 38.9 & 38.9 & 38.1 \\
\hline C-5 & 42.1 & 55.5 & 55.2 & 55.3 & 55.2 & 55.0 \\
\hline C-6 & 41.2 & 18.5 & 18.4 & 18.4 & 18.4 & 18.0 \\
\hline C-7 & 18.2 & 34.6 & 34.3 & 34.3 & 33.9 & 33.0 \\
\hline C-8 & 53.0 & 41.3 & 40.0 & 40.0 & 40.0 & 39.6 \\
\hline C-9 & 37.4 & 50.6 & 50.2 & 50.5 & 47.8 & 47.8 \\
\hline C-10 & 59.4 & 37.3 & 37.3 & 37.3 & 37.2 & 46.9 \\
\hline C-11 & 35.6 & 21.8 & 21.1 & 21.6 & 23.1 & 23.4 \\
\hline C-12 & 30.4 & 27.9 & 25.2 & 25.2 & 124.5 & 126.9 \\
\hline C-13 & 39.6 & 39.4 & 38.1 & 37.3 & 139.9 & 138.3 \\
\hline C-14 & 38.2 & 42.4 & 42.3 & 42.3 & 42.3 & 42.2 \\
\hline C-15 & 32.4 & 27.3 & 27.5 & 27.2 & 28.0 & 27.9 \\
C-16 & 35.9 & 36.9 & 35.6 & 29.2 & 26.7 & 24.3 \\
\hline C-17 & 29.9 & 34.7 & 43.1 & 47.8 & 33.9 & 48.4 \\
\hline C-18 & 42.7 & 48.9 & 48.4 & 48.8 & 59.1 & 53.0 \\
\hline C-19 & 35.3 & 36.5 & 48.0 & 47.8 & 39.6 & 39.1 \\
\hline C-20 & 28.1 & 140.1 & 151.0 & 150.6 & 39.6 & 38.9 \\
\hline C-21 & 32.7 & 119.1 & 29.7 & 29.8 & 31.5 & 30.7 \\
\hline C-22 & 39.2 & 42.5 & 40.0 & 33.9 & 41.5 & 36.2 \\
\hline C-23 & 6.8 & 28.2 & 28.0 & 28.0 & 28.0 & 29.8 \\
\hline C-24 & 14.6 & 15.6 & 15.4 & 15.4 & 16.0 & 17.4 \\
C-25 & 17.9 & 16.5 & 16.1 & 16.1 & 16.0 & 16.1 \\
\hline C-26 & 20.2 & 16.3 & 16.0 & 16.0 & 16.8 & 16.9 \\
\hline C-27 & 18.6 & 15.0 & 14.2 & 14.6 & 23.1 & 23.1 \\
\hline C-28 & 32.0 & 17.9 & 18.0 & 60.4 & 28.0 & 178.7 \\
C-29 & 35.0 & 22.8 & 109.3 & 109.7 & 17.5 & 17.0 \\
C-30 & 31.7 & 21.8 & 19.4 & 19.1 & 21.1 & 21.1 \\
\hline & & & & & & \\
\hline
\end{tabular}

respectively. The ${ }^{1} \mathrm{H}$ NMR spectrum shows signals at $\delta_{\mathrm{H}}$ $5.35(d, J=4.4 \mathrm{~Hz})$ and $\delta_{\mathrm{H}} 5.21-4.94$ attributed to alkenyl hydrogen atoms. The signal at $\delta_{\mathrm{H}} 3.70-3.45$ is characteristic of carbinol hydrogen atom. The ${ }^{13} \mathrm{C}$ NMR spectrum shows intense signals at $\delta_{\mathrm{C}} 140.7$ and 121.7 and less intense ones at $\delta_{\mathrm{C}} 138.4$ and 129.3 attributed to alkenyl carbon atoms, indicating that Group 4 is a mixture of two compounds with different proportions: sitosterol (7) and stigmasterol (8) (Costa et al. 2008). The integration of the ${ }^{1} \mathrm{H}$ NMR signals at $\delta_{\mathrm{H}} 5.35$ (assigned to H-6 of the sitosterol and stigmasterol) and $\delta_{\mathrm{H}}$ 5.21-4.94 (assigned to $\mathrm{H}-22$ and $\mathrm{H}-23$ of the stigmasterol) indicates a ratio of $75.5 \%$ stigmasterol and $24.5 \%$ sitosterol. Both the steroids are described for the first time in the genus Sacoglottis.

Stigmasterol inhibits cholesterol biosynthesis via inhibition of sterol $\Delta 24$-reductase in human Caco-2 and HL-60 cell lines (Batta et al. 2006). Various action mechanisms of the sitosterol have been proposed, including anti-inflammatory effects, 
alteration of cholesterol metabolism, and direct inhibition of prostate growth (Lowe and Ku 1996).

Therefore, some biological properties of the $S$. uchi can be attributed to the activities of the pentacyclic triterpenes 1 to 6 and steroids 7 and 8 .

\section{ACKNOWLEDGEMENTS}

The authors thank to Conselho Nacional de Desenvolvimento Científico e Tecnológico (CNPq), Fundação Coordenação de Aperfeiçoamento de Pessoal de Nível Superior (CAPES), Fundação de Amparo à Pesquisa do Estado de Minas Gerais (FAPEMIG), and Fundação de Amparo à Pesquisa do Estado do Amazonas (FAPEAM) for the financial support.

\section{REFERENCES}

Abreu, H.A.; Lagos, I.A.S.; Souza, G.P.; Piló-Veloso, D.; Duarte H.A.; Alcântara, A.F.C. 2008. Antioxidant activity of (+)-bergenin: a phytoconstituent isolated from the bark of Sacoglottis uchi Huber (Humireaceae). Organic \& Biomolecular Chemistry, 6: 2713-2718.

Abreu, V.G.C.; Takahashi, J.A.; Duarte, L.P.; Piló-Veloso, D.; Junior P.A.S.; Alves, R.O.; Romanha, A.J.; Alcântara, A.F.C. 2011. Evaluation of the bactericidal and trypanocidal activities of triterpenes isolated from the leaves, stems, and flowers of Lychnophora pinaster. Brazilian Journal of Pharmacognosy, 21: 615-621.

Batta, A.K.; Xu, G.; Honda, A.; Miyazaki, G.S. 2006. Stigmasterol reduces plasma cholesterol levels and inhibits hepatic synthesis and intestinal absorption in the rat. Metabolism Clinical and Experimental, 55: 292-299.

Bori, I.D.; Hung, H.Y.; Qian, K.; Chen, C.H.; Morris-Natscheke, S.L.; Lee, K.H. 2012. Anti-AIDS agents 88. Anti-HIV conjugates of betulin and betulinic acid with AZT prepared via click chemistry. Tetrahedron Letters, 53: 1987-1989.

Costa, H.N.R.; Santos, M.C.; Alcântara, A.F.C.; Silva, M.C.; França, R.C.; Piló-Veloso, D. 2008. Constituintes químicos e atividade antiedematogênica de Peltodon radicans (Lamiaceae). Química Nova, 31: 744-750.

Geetha, T.; Varalakshmi, P.; Latha, M. 1998. Effect of Tritepenes from Crataeva nurvala Stem Bark on Lipid Peroxidation in Adjuvant Induced Arthrits in Rats. Pharmacology Research, 37: 191-195.

Gentry, A. H. 1977. A Field Guide to the Families and Genera of Woody Plants of Northwest South America (Colombia, Ecuador, Peru), Conservation International, Washington, DC, USA.

Hasmeda, M.; Kweifio-Okai, G.; Macrides, T.; Polya, G.M. 1999. Selective inhibition of kukaryole protein kinases by antiinflammatory triterpenoids. Planta Medica 65: 14-18.

Kweifio-Okai, G. 1991. Antiinflammatory activity of a Ghanaian antiarthritic herbal preparation: I. Journal of Ethnopharmacology, 33: $263-267$.
Lowe, F.C.; Ku, J.C. 1996. Phytotherapy in treatment of benign prostatic hyperplasia: a critical review. Urolloy, 48: 12-20.

Magalhães, L.A.M.; Lima, M.P.; Marinho, H.A.; Ferreira, A.G. 2007. Identification of bergenin and carotenoids in the uchi (Endopleura uchi, Humiriaceae) fruit. Acta Amazonica, 37: 447-450.

Miranda, R.R.S.; Silva, G.D.F.; Duarte, L.P.; Fortes, I.C.P.; VieiraFilho, S.A. 2006. Structural determination of $3 \beta$-stearyloxyurs-12-ene from Maytenus salicifolia by 1D and 2D NMR and quantitative 13C NMR spectroscopy. Magnetc Resonance in Chemistry, 44: 127-131.

Mossi, A.J.; Cansian, R.L.; Carvalho, Z.A.; Dariva, C.; Oliveira, V.J.; Mazutti, M.; Filho, I.N.; Echeverrigaray, S. 2004. Extraction and characterization of volatile compounds in Maytenus ilicifolia, using high-pressure $\mathrm{CO}_{2}$. Fitoterapia, 75: 168-178.

Mullaer, F.B.; Kessler, J.H.; Medema, J.P. 2009. Betulin Is a Potent Anti-Tumor Agent that Is Enhanced by Cholesterol. PLoS One, 4: e5361.

Nguemeving, J.R.; Azebaze, A.G.B.; Kuete, V.; Carly, N.N.E.; Beng, V.P.; Meyer, M.; Blond, A.; Bodo, B.; Nkengfack, A.E. 2006. Laurentixanthones $\mathrm{A}$ and $\mathrm{B}$, antimicrobial xanthones from Vismia laurentii. Phytochemistry, 67: 1341-1346.

Politi, F.A.S.; Moreira, R.R.D.; Salgado, H.R.N.; Pietro, R.C.L.R. 2010. Preliminary tests on acute oral toxicity and intestinal motility with extract of pulverized bark of Endopleura uchi (Huber) Cuatrec. (Humiriaceae) in mice. Pan-Amazônica Saúde, 1:187-189

Santos-Torres, E.C.; Lopes, D.; Oliveira, R.R.; Carauta, C.A.; Falcão, B.; Kaplan, M.A.C.; Bergmann-Rossi, B. 2004. Antileishmanial activity of isolated triterpenoids from Pourouma guianensis. Phytomedicine, 11: 114-120.

Shanley, P.; Luz, L.; Swingland, I.R. 2002. The faint promise of a distant market: a survey of Belém's trade in non-timber forest products. Biodiversity and Conservation, 11: 615-636.

Silva, S.L.; Oliveira, V.G.; Yano, T.; Nunomura, R.C.S. 2009. Antimicrobial activity of bergenin from Endopleura uchi (Huber) Cuatrec. Acta Amazonica, 39: 187-192.

Surendra, K.; Corey, E.J. 2009. A Short Enantioselective Total Synthesis of the Fundamental Pentacyclic Triterpene Lupeol. Journal of the American Chemical Society, 131: 13928-13929.

Takahashi, H.; Kosaka, M.; Watanabe, Y.; Nakade, K.; Fukuyama, Y, 2003. Synthesis and neuroprotective activity of bergenin derivatives with antioxidant activity. Bioorganic \& Medicinal Chemistry, 11: 1781-1788.

Xie ,W.D.; Zhang, Q.; Li, P.L.; Jia, Z.J. 2005. Two triterpenoids and other constituents from Petasites tricholobus. Phytochemistry, 66: 2340-2345.

Recebido em: 26/07/2012

Aceito em: 14/02/2013 